\title{
Real Investment on Ground Water in Cauvery Basin Areas of Karnataka- An Economic Analysis
}

\author{
Raveesha S. ${ }^{1}$, M. G. Chandrakanth ${ }^{2}$, Shreeshail Rudrapur ${ }^{3}$, Nagaraj Kusagur ${ }^{4}$ and Ashoka N. ${ }^{5}$ \\ ${ }^{1}$ Agricultural Economics, College of Horticulture, Hiriyur, Karnataka (577 598), India \\ ${ }^{2}$ Institute for Social and Economic Change (ISEC) Nagarabhavi, Bengaluru, Karnataka (560 072), India \\ ${ }^{3}$ Agricultural Economics, College of Horticulture, Mudigere, Karnataka (577 132), India \\ ${ }^{4}$ Dept. of Horticulture ZAHRS, Mudigere, Chikkamangalore, UAHS, Shivamogga (577 204), India \\ ${ }^{5}$ Dept. of Agricultural Economics, COH, Munirabad UHS, Bhagalkot, Karnataka (583 233), India
}

\section{Corresponding Author}

Raveesha S.

e-mail: poonaravi1@gmail.com

\begin{abstract}
Article History
Article ID: IJEP0314

Received in 03 ${ }^{\text {rd }}$ December, 2019

Received in revised form $17^{\text {th }}$ December, 2019

Accepted in final form $26^{\text {th }}$ December, 2019
\end{abstract}

\begin{abstract}
In this study, irrigation wells located under canal command (GWCI) (Gadabanaalli), the irrigation wells located under tank command (GWTI) (Echanur), receiving the Hemavathy river water, with a water spread of 363 acres and another village Kibbanahalli where groundwater wells are located independently (called groundwater under sole irrigation GWSI), which depend only on rainfall source have been considered. Only farmers possessing irrigation wells in each of the three scenarios were chosen. A random sample of 35 farmers was drawn from each of the three scenarios, thus, totaling 105 for the purpose of this study. It was observed that the real investment was falling over the years with a range of Rs. 3137 to Rs. 6255 even though the nominal investment ranged between Rs. 19100 and Rs. 66600 for farmers in GWTI. Real investment on irrigation wells shows a declining trend in all the three situations. Thus, the real cost of groundwater is falling over time not exhibiting ricardian scarcity. In GCTI farmers, the real investment for working well was falling over the years with a range of Rs. 1815 to Rs. 6225 even though the nominal investment ranged between Rs. 20600 and Rs. 73987, the mean real investment per well was Rs. 5103, and the mean nominal investment per well was Rs. 40352. Considering the nominal cost of extraction of groundwater, it was clear that there was an increasing trend due to inflation and associated factors. However, the real cost of extraction was found to be consistent over the years.
\end{abstract}

Keywords: Amortization, bore wells, investment, real cost

\section{Introduction}

In this study, the economics of groundwater recharge is studied in Tumkur district in hard rock areas of Karnataka State. The study area is covered by the Hemavathy river basin. In addition, in parts of the central dry agro-climatic zone of Karnataka, in the cauvery basin, the river Hemavathi is put to productive use. For example, in the process of getting the crucial and vital drinking water for the city of Tumkur, the riparian areas on either sides of the flow of the river are benefited from groundwater recharge. The river Hemavathy, a tributary of river Cauvery, has its origin in Ballarayana Durga in Chikmagalore district of the Western Ghats at 1219 meters above MSL. The river flows through Chikkamagalooru, Hassan District and Mysore district before joining the Kaveri near Krishnarajasagara. The Hemavathy masonry dam is constructed in Gorur in Hassan District which impounds 78 TMC of water assuming 50\% dependability. The reservoir fills between June and September, during the south west monsoons and the depletion period is October to May. The Tumkur branch canal from the Hemavathy left bank canal which brings drinking water to Tumkur city is 240 kilometers long carrying 1429 cusecs of water.

The district mainly depends upon ground water for drinking and irrigation purposes. According to CGWB, about $90 \%$ of the irrigation and drinking requirements are met from ground water. This has resulted in over exploitation in about $55 \%$ area in the district. In general, water levels are showing declining trend. About 1179 dug wells and 1687 bore wells have dried up in the district. Also, there is decrease of potable water in fluoride-affected areas due to drying of phreatic aquifer. Hence to overcome these problems, it is recommended to adopt scientific management of ground water resource. Further, development should be allowed in areas which are categorized as safe and semi critical with caution. Vaidyanathan (1994) opined that the cost of providing irrigation consists of three main elements, namely operation and maintenance expenses, depreciation and interest on capital invested. Mass awareness programmes should be conducted for public awareness about the limited availability of ground water resource. Farmers should be educated to grow 
less water intensive crops and adopt micro irrigation system. This study is a modest attempt towards the economics of groundwater irrigation under three situations of recharge in Tiptur taluk, Tumkur district of Karnataka. Here, the irrigation wells located under canal command (GWCI) (Gadabanaalli), the irrigation wells located under tank command (GWTI) (Echanur), receiving the Hemavathy river water, with a water spread of 363 acres and another vilallge Kibbanahalli where groundwater wells are located independently or canal or tank irrigation command (called groundwater under sole irrigation GWSI), which depend only on rainfall source have been considered.

\section{Materials and Methods}

\subsection{Selection of sample villages and sampling}

For identifying the sample villages, the resource persons from department of agriculture, irrigation, biodiversity, forestry (Vanavikasa) cooperative societies and Gram panchayats in the villages were approached. For comparison of the relative performance of the groundwater recharge in Tiptur taluk, irrigation wells located under Hemavathy canal command (GWCI), the system tank command (Echanoor) (GWTI) and the groundwater wells under sole irrigation (GWSI), where the recharge is largely by rainfall (Kibbanahalli) were chosen in consonance with study objectives in the Hemavathy river sub-basin of Cauvery river basin as under:

a. Groundwater wells for irrigation located under system tank irrigation command (GWTI): such wells are recharged by system irrigation tank (sample of 35 farmers).

b. Groundwater wells for irrigation located under canal command (GWCI): such wells are recharged by canal irrigation command (sample of 35 farmers).

c. Groundwater wells for irrigation located independently of tank or canal command (GWSI): such wells are recharged largely by rainfall and acts as a control situation (sample of 35 farmers).

\subsection{Sample size}

For this study, only farmers possessing irrigation wells in each of the three scenarios were chosen. Hence, a random sample of 35 farmers was drawn from each of the three scenarios, thus, totaling 105 for the purpose of this study.

\subsection{Analytical frame work}

\subsubsection{Amortized cost of bore well}

In order to arrive at the annual share of groundwater irrigation cost, the well investment has been amortized. It varies with amount of capital investment, age of the well, interest rate, year of construction. Amortization cost of well was worked out by adopting the following procedure:

Amortized cost of irrigation bore well $=$ (Amortized cost of BW + Amortized cost of pump set + Amortized cost of conveyance + Amortized cost of over ground structure + Repairs and maintenance cost of pump set and accessories)

Amortized cost of bore well= [(Compounded cost of bore well) $\left.*(1+d)^{A A *} d\right],\left[(1+d)^{A A}-1\right]$
Where,

$A A=$ Average Age of bore well

$\mathrm{BW}=$ Bore Well

$\mathrm{d}=$ Discount rate considered at $2 \%$

Compounded cost of BW $=$ Historical cost of BW* $(1+i)^{\text {(2009-year }}$ of drilling)

Where,

$\mathrm{i}=$ Compound rate of $2 \%$

A modest discount rate of two $2 \%$ is considered for amortizing the cost of irrigation well to represent the compound rate of interest in the costing well components like construction cost, drilling cost, pump set, and accessories and so on.

\subsection{Estimation of barnet and morse scarcity}

2.4.1. Estimation of real cost of groundwater extraction for all wells (functioning and failed)

The functioning well refers to the irrigation wells functioning up to the year of field data collection, October November 2008. The failed well refers to the wells which were not yielding water at the time of field data collection. The farmers may have a combination of functioning and failed wells drilled during different years based on their resource endowments and economic capacities. Therefore, the nominal investment/s on wells which were not functional at the time of data collection have been added and considered "for the year of functioning wells" after deflating by the Wholesale Price Indices. This was attempted in order to accommodate investment on failed wells also on the farm which needs to be recovered from the functioning well by the farmer. Thus, the Real Investment on well includes both real investment on functioning and failed wells.

\subsubsection{Estimation of real cost of groundwater extraction per} functioning well

In order to work out the nominal and real investment per well, it is necessary to know whether the well is functioning or not at the time of field data collection. However, since farmers encounter both well failures (premature as well as initial failure) and well successes, investment on both functioning and failed wells has to be considered. Among the two, investment on functioning well is more appropriate since the farmer recover his total investment only from functioning well. In the study area, the chronology of well drilling dates back to 1984 and continues to 2008 as a span of 24 years. In each of these years, though theoretically we can expect that functioning well is present in every year, it was found that only the wells drilled in the years 1986, 1988, 1989, 1990, 1993, 1994, 1996, 1997, 1998, 1999, 2000, 2002, 2003, 2004, 2005, 2006 and 2008 were functioning. Therefore, the information on real cost pertains to only these years.

\subsection{Other measures of groundwater scarcity included}

a. Real investment per acre inch of groundwater extracted

Here real investment on all irrigation wells is divided by the number of working wells to obtain the real investment per well. This is further divided by the groundwater extracted in 2008, to obtain the real investment per acre inch of groundwater. 
b. Real investment per acre of gross irrigated area

Here real investment on all irrigation wells is divided by the number of working wells to obtain the real investment per well. This is further divided by the gross irrigated area in 2008, to obtain the real investment per acre.

\section{Results and Discussion}

3.1. Real investment per well for sample farmers in GWTI, GWCI and GWSI

The farmers may have a combination of functioning and failed wells drilled during different years based on their resource endowments and economic capacities, thus real investment on well includes both real investment on functioning and failed wells. It was observed that the real investment was falling over the years with a range of Rs. 3137 to Rs. 6255 even though the nominal investment ranged between Rs. 19100 and Rs. 66600 for farmers in GWTI (Table 1).

\begin{tabular}{lccccc}
\hline \multicolumn{5}{l}{ Table 1: Real investment per well for sample farmers in GWTI } \\
\hline Sl. No. & YD & NI & WPI & RI & RII \\
\hline 1. & 1984 & 19100 & 338.4 & 5644 & 100 \\
2. & 1985 & 22380 & 357.8 & 6255 & 110.82 \\
3. & 1986 & 21900 & 376.8 & 5812 & 102.97 \\
4. & 1988 & 28200 & 433.8 & 6501 & 115.18 \\
5. & 1989 & 29130 & 466.1 & 6250 & 110.72 \\
6. & 1990 & 26157 & 513.9 & 5089 & 90.17 \\
7. & 1992 & 25400 & 643.3 & 3948 & 69.95 \\
8. & 1993 & 23720 & 697.1 & 3403 & 60.29 \\
9. & 1994 & 35700 & 772.7 & 4620 & 81.85 \\
10. & 1995 & 38250 & 775.8 & 4930 & 87.35 \\
11. & 1996 & 41850 & 885.0 & 4729 & 83.78 \\
12. & 1997 & 45440 & 959.2 & 4737 & 83.93 \\
13. & 1998 & 48020 & 980.8 & 4896 & 86.75 \\
14. & 1999 & 48000 & 1012.8 & 4739 & 83.97 \\
15. & 2000 & 47700 & 1085.3 & 4395 & 77.87 \\
16. & 2002 & 50400 & 1162.7 & 4335 & 76.80 \\
17. & 2003 & 38463 & 1226.1 & 3137 & 55.58 \\
18. & 2004 & 58806 & 1305.6 & 4504 & 79.80 \\
19. & 2005 & 66600 & 1363.5 & 4885 & 86.54 \\
20. & 2006 & 60033 & 1436.6 & 4179 & 74.04 \\
21. & 2008 & 52640 & 1505.0 & 3498 & 61.97 \\
Average & & 39423 & & 4785 & \\
\hline YD Year & & & & \\
\hline
\end{tabular}

YD: Year of drilling; NI: Nominal investment (Rs.); WPI: Wholesale price index (Base:1970-71=100); RI: Real investment (Rs.); RII: Real investment index (Base:1970-71=100); Note: Investment per well includes drilling, casing, pump and accessories, conveyance pipes, electrical installation charges
For the farmers in $\mathrm{GWCl}$, the nominal investment ranged from Rs. 20600 to Rs. 93986 while the real investment ranged from Rs. 1815 to Rs. 6225 (Table 2). In GWSI, the nominal investment ranged from Rs. 17370 to Rs. 84703 while the real investment

\begin{tabular}{|c|c|c|c|c|c|}
\hline SI. No. & YD & $\mathrm{NI}$ & WPI & $\mathrm{RI}$ & RII \\
\hline 1. & 1985 & 20600 & 357.8 & 5757 & 100 \\
\hline 2. & 1986 & 23230 & 376.8 & 6165 & 107.08 \\
\hline 3. & 1988 & 27000 & 433.8 & 6225 & 108.11 \\
\hline 4. & 1989 & 26800 & 466.1 & 5750 & 99.87 \\
\hline 5. & 1990 & 29150 & 513.9 & 5672 & 98.52 \\
\hline 6. & 1991 & 35500 & 584.5 & 6073 & 105.48 \\
\hline 7. & 1992 & 30700 & 643.3 & 4772 & 82.88 \\
\hline 8. & 1993 & 31470 & 697.1 & 4515 & 78.41 \\
\hline 9. & 1994 & 42025 & 772.7 & 5439 & 94.46 \\
\hline 10. & 1995 & 41600 & 775.8 & 5362 & 93.13 \\
\hline 11. & 1996 & 42320 & 885.0 & 4782 & 83.06 \\
\hline 12. & 1998 & 46100 & 980.8 & 4700 & 81.64 \\
\hline 13. & 1999 & 48620 & 1012.8 & 4800 & 83.38 \\
\hline 14. & 2000 & 57200 & 1085.3 & 5270 & 91.54 \\
\hline 15. & 2001 & 66200 & 1124.4 & 5888 & 102.26 \\
\hline 16. & 2002 & 45420 & 1162.7 & 3906 & 67.85 \\
\hline 17. & 2003 & 54015 & 1226.1 & 4405 & 76.52 \\
\hline 18. & 2004 & 73987 & 1305.6 & 5667 & 98.43 \\
\hline 19. & 2005 & 24750 & 1363.5 & 1815 & 31.53 \\
\hline Average & & 40352 & & 5103 & \\
\hline
\end{tabular}

YD: Year of drilling; NI: Nominal investment (Rs.); WPI: Wholesale price index (Base:1970-71=100); RI: Real investment (Rs.); RII: Real investment index (Base:1970-71=100); Note: Investment per well includes drilling, casing, Pump and accessories, conveyance pipes, electrical installation charges

ranged from Rs. 4176 to Rs. 7396 (Table 3).

Real investment on irrigation wells shows a declining trend in all the three situations viz., GWTI, GWCI and GWSI farms. Thus the Real Cost of groundwater is falling over time not exhibiting Ricardian scarcity. This does not mean that there is no Malthusian scarcity. The real investment was falling over the years with a range of Rs. 3403 to Rs. 6501 even though the nominal investment ranged between Rs. 19100 and Rs. 66600 for farmers in GWTI while for the farmers in GWSI the nominal investment ranged between Rs. 17370 and Rs. 84703, while real investment ranged from Rs. 4176 to Rs. 7396.

In GCTI farmers, the real investment for working well was falling over the years with a range of Rs. 1815 to Rs. 6225. Even though the nominal investment ranged between Rs. 20600 and Rs. 73987, the mean real investment per well was Rs. 5103 


\begin{tabular}{lccccc}
\hline \multicolumn{6}{l}{ Table 3: Real investment per well for sample farmers in GWSI } \\
\hline Sl. No. & YD & NI & WPI & RI & RII \\
\hline 1. & 1985 & 17370 & 357.8 & 4855 & 100 \\
2. & 1986 & 20400 & 376.8 & 5414 & 111.52 \\
3. & 1987 & 24480 & 403.9 & 6060 & 124.83 \\
4. & 1988 & 32080 & 433.8 & 7396 & 152.34 \\
5. & 1989 & 26540 & 466.1 & 5694 & 117.29 \\
6. & 1990 & 31348 & 513.9 & 6100 & 125.64 \\
7. & 1992 & 36900 & 643.3 & 5736 & 118.15 \\
8. & 1993 & 29580 & 697.1 & 4244 & 87.41 \\
9. & 1996 & 44438 & 885.0 & 5021 & 103.43 \\
10. & 1998 & 55270 & 980.8 & 5635 & 116.08 \\
11. & 1999 & 55085 & 1012.8 & 5439 & 112.03 \\
12. & 2000 & 63260 & 1085.3 & 5829 & 120.06 \\
13. & 2001 & 46955 & 1124.4 & 4176 & 86.02 \\
14. & 2002 & 56785 & 1162.7 & 4884 & 100.60 \\
15. & 2003 & 63353 & 1226.1 & 5167 & 106.43 \\
16. & 2004 & 78930 & 1305.6 & 6046 & 124.53 \\
17. & 2005 & 70788 & 1363.5 & 5192 & 106.95 \\
18. & 2006 & 84703 & 1436.6 & 5896 & 121.45 \\
19. & 2007 & 63880 & 1505.0 & 4245 & 87.43 \\
Average & & 47481 & & 5422 & \\
\hline YD. & & & & \\
\hline
\end{tabular}

YD: Year of drilling; NI: Nominal investment (Rs.); WPI: Wholesale price index (Base:1970-71=100); RI: Real investment (Rs.); RII: Real investment index (Base:1970-71=100); Note: Investment per well includes drilling, casing, pump and accessories, conveyance pipes, electrical installation charges

and the mean nominal investment per well was Rs. 40352. In GWSI farmers, the real investment per well was falling over the years with a range of Rs. 4176 to Rs. 7396 . Even though the nominal investment ranged between Rs. 17370 and Rs.
84703, the mean real investment per well was Rs. 5422 and the mean nominal investment per well was Rs.4748. In case of well irrigated farms, the irrigation cost was Rs. $3930 \mathrm{acre}^{-1}$ and this was fully borne by the farmers (Yatheesha, 2002; Nagaraj et al., 2003). Applying Pontryagin's maximum principle to find the economically sustainable path of groundwater extraction, results indicated that by following the optimal path, the life of groundwater wells will increase by an additional 8, 17 and 24 years, respectively in GWSI, GWTI and GWCI areas over myopic (or uncontrolled) extraction (Chaitra and Chandrakanth, 2005).

\section{Conclusion}

This study apparently is a pointer towards the role of channel water linkage in promoting ground water recharge. The farms served by System Percolation Tank (GWTI) and Canal Percolation $(\mathrm{GWCl})$ have registered the highest net returns compared with farms under the command of Non-System Tank (GWSI). This indicates the supremacy of the performance of GWTI and $\mathrm{GWCl}$ in heralding agricultural development as irrigation tanks are multipurpose entities.

\section{References}

Chaitra, B.S., Chandrakanth, M.G., 2005. Optimal extraction of groundwater for irrigation: synergies from surface water bodies in tropical India. Water Policy 7, 597-611.

Nagaraj, N., Chandrashekar, H., Yatheesh, H.S., 2003. Sustainability and equity implications of groundwater depletion in hard rock areas of Karnataka: an economic analysis. Indian Journal of Agricultural Economics 58, 438-447.

Vaidyanathan, A. 1994. Report on pricing of irrigation water. Indian Journal of Agricultural Economics 49, 107-123.

Yatheesha, Y.S., 2002. Sustainable ground water management in overexploited areas of central dry zone of Karnataka: some alternative options- an economic analysis. M.Sc. thesis, university of agricultural sciences, Bangalore. 